\title{
Nutrient Dynamics of an Aquaponic System in Southern Thailand
}

\author{
Somsak Maneepong ${ }^{1}$ \\ ${ }^{1}$ School of Agricultural Technology, Walailak University, Nakhon Si Thammarat, Thailand \\ Correspondence: Somsak Maneepong, School of Agricultural Technology, Walailak University, Nakhon Si \\ Thammarat, 80161, Thailand. E-mail: msomsak@wu.ac.th
}

Received: August 6, 2019

doi:10.5539/jas.v11n17p57
Accepted: September 6, $2019 \quad$ Online Published: October 15, 2019

URL: https://doi.org/10.5539/jas.v11n17p57

The research is financed by the Thailand Research Fund and Walailak University.

\begin{abstract}
Aquaponics is an integrated system of recirculation aquaculture and soilless culture that mainly aims to reduce water requirements, reduce waste discharge and maximize nutrient use. In the present study, an aquaponic system consisting of a $500 \mathrm{~L}$ fish tank, sedimentation and $\mathrm{pH}$ control tank, degassing tank and three vegetable growing beds was assembled and tested for 17 weeks. Fifty Nile tilapias (Oreochromis niloticus) were reared and fed thrice daily with a complete diet containing $32 \%$ protein. Buffer of solid rocks (dead corals) were installed for $\mathrm{pH}$ control. Water convolvulus (Ipomoea aquatica) and Tokyo Bekana (Brassica rapa) were rotationally grown at different growth stages. Water samples were collected once a week to analyze $\mathrm{pH}$ and $\mathrm{NH}_{3} / \mathrm{NH}_{4}{ }^{+}, \mathrm{NO}_{3}{ }^{-}$, $\mathrm{H}_{2} \mathrm{PO}_{4}{ }^{-} / \mathrm{HPO}_{4}{ }^{2-}, \mathrm{SO}_{4}{ }^{2-}, \mathrm{K}, \mathrm{Na}, \mathrm{Ca}, \mathrm{Mg}$ and $\mathrm{Fe}$ concentrations. Fish weight increased from $50 \mathrm{~g} /$ fish at the beginning of the experiment to $228 \mathrm{~g} /$ fish after 15 weeks. Water $\mathrm{pH}$ increased from 6.0 before rearing to 7.0 on the $4^{\text {th }}$ week and varied over the range of 6.9 to 7.0 until the end of the experiment without any additional acid or alkali. Total $\mathrm{NH}_{3} / \mathrm{NH}_{4}{ }^{+}$increased to $10.2 \mathrm{mg}-\mathrm{N} / \mathrm{L}$ on the $2^{\text {nd }}$ week and rapidly declined to levels below 2.0 mg-N/L. Phosphate, $\mathrm{SO}_{4}{ }^{2-}, \mathrm{Na}$ and $\mathrm{Mg}$ accumulated in the system, whereas $\mathrm{Ca}$ gradually increased and reached equilibrium at $47 \pm 2 \mathrm{mg} / \mathrm{L} . \mathrm{K}$ and $\mathrm{NO}_{2}{ }^{-} / \mathrm{NO}_{3}{ }^{-}$varied considerably at concentrations lower than the general requirement of the vegetables. The first crops of vegetables initially grew well, but growth rates declined remarkably and latter crops showed complex nutrient deficiency. The system could be maintained for 17 weeks without waste discharge.
\end{abstract}

Keywords: aquaponics, aquaculture, Nile tilapia, plant nutrient

\section{Introduction}

Aquaculture simultaneously requires charging of large volumes of input water and discharging of large volumes of waste water. An integrated system of recirculating aquaculture and soilless culture has been developed to solve these problems. Waste from aquatic animals is converted to plant nutrients by microorganisms. The nutrients are removed by plants in a soilless subsystem, and the clean water is recirculated back to the aquaculture subsystem (Lennard \& Leonard, 2004; Rakocy et al., 2006; Edwards, 2015; Perez-Urrestarazu et al., 2019). Several types of aquaponics systems have been proposed; their principal components include a fish rearing tank, biofilter, clarifier and soilless culture subsystem (FAO, 2014; Wongkiew et al., 2017). Fish, microorganisms and plants require different nutrients and environmental conditions. Fish requires Na but plants do not require. The pellet feed of fish usually contains high $\mathrm{Na}$ and low $\mathrm{K}$ concentrations. Unfortunately, high $\mathrm{Na}$ interferes with the nutrient uptake of plants, and plants require large amounts of $\mathrm{K}$. Thus, the Na concentration should be maintained at levels lower than $50 \mathrm{mg} / \mathrm{L}$, and $\mathrm{K}$ has to supplement in to the system (Rakocy et al., 2006). Salt concentrations in the system increase because of the accumulation of inorganic ions such as $\mathrm{NO}_{3}^{-}$, $\mathrm{H}_{2} \mathrm{PO}_{4}^{-} / \mathrm{HPO}_{4}{ }^{2-}, \mathrm{SO}_{4}{ }^{2-}, \mathrm{Cl}^{-}, \mathrm{Na}^{+}, \mathrm{K}^{+}, \mathrm{Ca}^{2+}$ and $\mathrm{Mg}^{2+}$; causing increases in total dissolved solid and electrical conductivity (EC). Nile tilapia grows well at the EC lower than $1.0 \mathrm{mS} / \mathrm{cm}$, but most soilless growing plants require higher salt concentrations $(1.5$ to $2.5 \mathrm{mS} / \mathrm{cm})$. Salt from the decomposition of fish excrement alone generally cannot raise EC to $1.0 \mathrm{mS} / \mathrm{cm}$, therefore there is a gap for adding some more nutrient into the systems. Nutrient ratios in such systems vary greatly according to the rate of fish excretion, mineralization and plant assimilation (Seawright et al., 1998). Optimum concentrations and ratios for plant growth are difficult to 
maintain, leading to reduction in plant yield over extended culture period. Suitable plant species for the aquaponics are restricted to species well adapted to low nutrient concentrations and wide nutrient ratios.

Intensive fish cultivation is general practiced for aquaponics to produce sufficient amounts of plant nutrients and reduce operating cost. Total ammonia $\left(\mathrm{NH}_{3} / \mathrm{NH}_{4}{ }^{+}\right)$accumulation in a fish tank is a serious concern because the compound is highly toxic to the fish. Unionized form $\left(\mathrm{NH}_{3}\right)$ and protonated form $\left(\mathrm{NH}_{4}{ }^{+}\right)$are in equilibrium and the concentration of each form depends on the total concentration, $\mathrm{pH}$ and water temperature (Lekang, 2013; Eshchar et al., 2006; Kamal, 2006; Hargreaves \& Tucker, 2004). $\mathrm{NH}_{3}$ is prevalent at high $\mathrm{pH}$ and toxic to fish at levels above $0.05 \mathrm{mg}-\mathrm{N} / \mathrm{L}$ (Tyson et al., 2008). Plants uptake $\mathrm{NH}_{4}{ }^{+}$, whereas $\mathrm{NH}_{3}$ is a substrate for nitrification. Ammonia must be removed from the fish tank and converted to its less toxic form $\left(\mathrm{NO}_{3}{ }^{-}\right)$by nitrification. The nitrification produces 2 moles of $\mathrm{H}^{+}$for each mole of ammonia, thereby $\mathrm{pH}$ of the water decreases simultaneously. The optimum $\mathrm{pH}$ range for nitrification is 7.0 to 9.0 , whereas most soilless plants perform best growing in the range of 5.5 to 6.5. Thus, the water $\mathrm{pH}$ has to be compromised and maintained close to 7.0 by frequently adding of alkali materials such as $\mathrm{KOH}, \mathrm{NaOH}, \mathrm{Ca}(\mathrm{OH})_{2}, \mathrm{Mg}(\mathrm{OH})_{2}, \mathrm{CaCO}_{3}, \mathrm{MgCO}_{3}, \mathrm{CaMg}\left(\mathrm{CO}_{3}\right)_{2}$ or $\mathrm{NaHCO}_{3}$. Na-containing materials should be avoided because high $\mathrm{Na}$ concentrations interfere with $\mathrm{K}$ and $\mathrm{Ca}$ uptake and are toxic to plants (Lekang, 2013; Rakocy, 2012; Rakocy et al., 2006; Lennard \& Leonard, 2004; Seawright et al., 1998). This practice requires intensive labor, low precision and high operating cost especially for a commercial scale.

The present study was conducted to examine variations in nutrient concentrations in an aquaponic system and effectiveness of $\mathrm{pH}$ control. The effects of water properties and nutrient ratios on the growth rates of fish and vegetables were also examined.

\section{Materials and Methods}

\subsection{System Description}

An aquaponic system consisting of a $500 \mathrm{~L}$ fish rearing tank, sedimentation and $\mathrm{pH}$ control tank, degas tank, three floating raft growing troughs and a sump tank was assembled (Figure 1). The upper part of the fish rearing tank was cylindrical, while the bottom part was funnel-shaped. Five air diffusers connected to a 58 Watts aquarium air compressor were installed to supply $\mathrm{O}_{2}$ into the water. A drain pipe a diameter of 2 inches was connected from the center of the bottom of the fish tank to the $175 \mathrm{~L}$ sedimentation tank. A $25 \mathrm{~L}$ cylindrical tank was installed inside the sedimentation tank and filled with dead coral. A drain pipe was connected from the inner tank to the $200 \mathrm{~L}$ degassing tank. Water from the degassing tank was continuously siphoned to the growing troughs. Each trough had a growing area of $0.75 \mathrm{~m}^{2}$ and was installed with five air diffusers and filled with bio-balls as the microbial substrate. The water depth in the troughs was maintained at $15 \mathrm{~cm}$ and overflowed to the sump tank. A submersible pump controlled by a floating switch was installed in the sump tank to recirculate the water back to the fish tank. The water level in the fish tank was maintained between 60 to $70 \mathrm{~cm}$ depth, and the recirculation water was aslant flowed back into the fish tank to generate centrifugal force for removing sediment from the tank. The water in the system was totally recirculated with some compensation weekly for evaporation loss.

\subsection{Operation and Sample Analysis}

Fifty Nile tilapias (Oreochromis niloticus) were reared and fed manually thrice daily with a complete diet containing $32 \%$ protein. The mean weight of the fish at the beginning of the experiment was $50.8 \mathrm{~g} / \mathrm{fish}$. Fifteen fish were sampled monthly for measurement of weight gain. Water convolvulus (Ipomoea aquatica) and Tokyo Bekana (Brassica rapa) were seeded for 1 week and transplanted to the growing troughs for 3 weeks. The vegetables were grown rotationally to maintain equal ages in the system throughout the experiment. The vegetables were harvested once a week, their roots were removed, and their fresh weights were determined. Fe-DTPA $(11.3 \% \mathrm{Fe})$ was added into the system during the second week at a rate of $15 \mathrm{mg} / \mathrm{L}$. Water samples from the fish tank were collected once a week to analyze $\mathrm{pH}$ and $\mathrm{NH}_{3} / \mathrm{NH}_{4}{ }^{+}, \mathrm{NO}_{3}{ }^{-}$, phosphate, $\mathrm{SO}_{4}{ }^{2-}, \mathrm{K}, \mathrm{Na}, \mathrm{Ca}$, $\mathrm{Mg}$ and $\mathrm{Fe}$ concentrations. Water $\mathrm{pH}$ was determined by a $\mathrm{pH}$ meter, $\mathrm{NH}_{3} / \mathrm{NH}_{4}{ }^{+}$concentration was determined by distillation and titration method, and $\mathrm{NO}_{3}{ }^{-}$and $\mathrm{SO}_{4}{ }^{2-}$ concentrations were determined by using ion chromatography (Rayment \& Higginson, 1992). Phosphate concentrations were determined by the molybdenum blue method (Rayment \& Higginson, 1992), and $\mathrm{K}, \mathrm{Na}, \mathrm{Ca}, \mathrm{Mg}$ and Fe concentrations were determined using atomic absorption spectrophotometry (Buurman et al., 1996). New solid excrement was sampled once a week, dried at $65{ }^{\circ} \mathrm{C}$ and combined together for chemical analysis. $\mathrm{C}$ and $\mathrm{N}$ contents in diet and excrement samples were determined using the dry combustion method (Buurman et al., 1996; Rayment \& Higginson, 1992). Other portions of the diet and excrement samples were digested with a $2: 1$ mixture of $\mathrm{HNO}_{3}: \mathrm{HClO}_{4}$ for $\mathrm{P}, \mathrm{K}, \mathrm{Na}, \mathrm{Ca}$, $\mathrm{Mg}, \mathrm{Fe}, \mathrm{Mn}, \mathrm{Zn}$ and $\mathrm{Cu}$ analysis (Jones, 2001). The $\mathrm{P}$ concentration was determined by the vanadomolybdate 
method, while the concentrations of metals were determined using atomic absorption spectrophotometry (Jones, 2001).

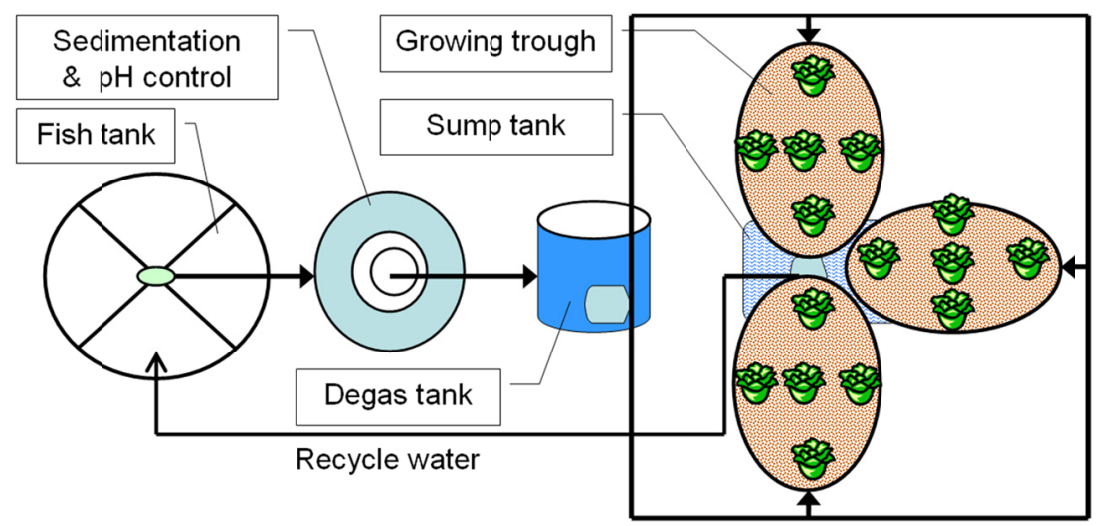

Figure 1. Schematic diagram of the aquaponic system used in this study

\section{Results and Discussion}

\subsection{Fish Performance}

The aquaponic system was operated continuously for 17 weeks with totally recirculation. Additional water was filled into the fish tank 2 or 3 times weekly for compensation of evaporation loss. Fish survival rate was $100 \%$, no mortality occur during the study period. The fish weight increased from $50.8 \mathrm{~g} /$ fish to $228.0 \mathrm{~g} /$ fish on the third month. Mean weights increased by $110.7,14.8$ and $51.7 \mathrm{~g} /$ fish on the first, second and third month, respectively; and the overall monthly increment was $54.6 \mathrm{~g} /$ fish. Great reductions in weight increment after the first month indicate defect in the system. Feeding rates were nearly constant from the beginning of the experiment to the $9^{\text {th }}$ week, sharply decreased on the $10^{\text {th }}$ and $11^{\text {th }}$ weeks and recovered after the flow rate of the water was corrected (Figure 2). The feeding rates were closely related to recirculation rate of the system. The recirculation rate gradually dropped and nearly stopped on the $10^{\text {th }}$ week of the experiment because of clocking in the pipes. Siphon of water from the degas tank to the growing troughs could not provide sufficient pressure to drive the suspended particles to flow through the pipes. After the problem was corrected, the recirculation rate increased and the feeding rate also recovered. Flow rate of water in a high-stock density aquaponic system is generally recommended to be twice of the total volume per hour to avoid reductions of dissolved $\mathrm{O}_{2}$ and accumulation of $\mathrm{NH}_{3} / \mathrm{NH}_{4}{ }^{+}$in the fish tank. However, at low stock densities the flow rate may be reduced to one unit of total volume per hour (FAO, 2014). The feed conversion ratio (FCR) of this study was still relatively low (1.46) comparison to the other studies (Kamal, 2006; Rakocy et al., 2006).

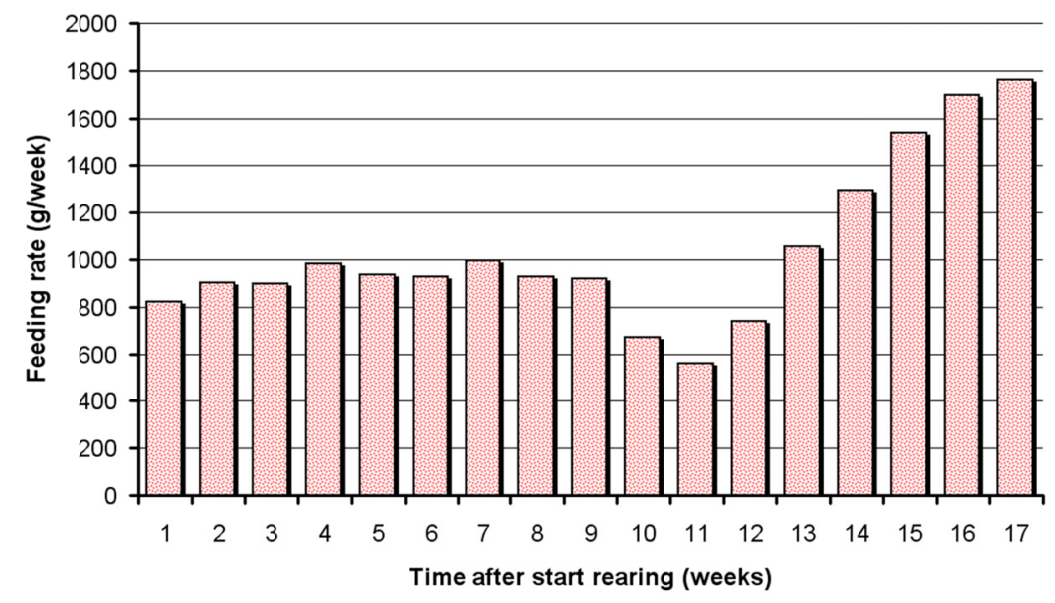

Figure 2. Variation of the feeding rate of fish over time 


\subsection{Plant Performance}

The yields of water convolvulus and Tokyo Bekana at the beginning of culture were better than those in the middle and the final stages (Table 1). The yields of both vegetables decreased considerably with repeated cultivation. Most of the nutrient concentrations at the beginning of culture were low except Fe, but plant growth was excellent. The plant performance indicates that balance of nutrients, rather than their actual concentrations, is more important for plant growth. Yields of the water convolvulus were substantially higher than yields of the Tokyo Bekana in every stage of culture, indicating that the former is more suitable for aquaponic systems than the latter. The Tokyo Bekana grown after $7^{\text {th }}$ week deteriorated under strong sunlight, indicating a problem with evapotranspiration which is related to $\mathrm{K}$ deficiency. A complicated nutrient disorder (chlorosis, interveinal chlorosis and stunning) was observed in the Tokyo Bekana after $7^{\text {th }}$ week. A similar problem has been reported for lettuce (Seawright et al., 1998). However, tip-burn was not found in the current study. Lam et al. (2015) found that a 3:1 volume ratio of hydroponic trough to rearing tank results in optimal plant growth. The exchange rate of water in the growing troughs is also a factor influencing plant growth. Buzby, Waterland, Semmens \& Lin (2016) found that most of crops they grown show higher biomass at a higher flow rate $(75.7 \mathrm{~L} / \mathrm{min})$ than at a lower rate $(18.9 \mathrm{~L} / \mathrm{min})$.

Table 1. Yields of water convolvulus and Tokyo Bekana (fresh weight) grown at different stages

\begin{tabular}{|c|c|c|c|}
\hline \multirow[b]{2}{*}{ Vegetables } & \multicolumn{3}{|c|}{ Vegetable yield $\left(\mathrm{kg} / \mathrm{m}^{2}\right)$} \\
\hline & $\begin{array}{l}\text { Beginning stage } \\
\left(1^{\text {st }}-6^{\text {th }} \text { week }\right)\end{array}$ & $\begin{array}{l}\text { Middle stage } \\
\left(7^{\text {th }}-12^{\text {th }} \text { week }\right)\end{array}$ & $\begin{array}{l}\text { Last stage } \\
\left(13^{\text {th }}-17^{\text {th }} \text { week }\right)\end{array}$ \\
\hline water convolvulus & $3.74 \pm 0.32$ & $3.06 \pm 0.30$ & $2.60 \pm 0.03$ \\
\hline Tokyo Bekana & $1.95 \pm 0.04$ & $0.73 \pm 0.14$ & $0.27 \pm 0.06$ \\
\hline
\end{tabular}

\subsection{Chemical Compositions of Diet and Solid Excrement}

The chemical compositions of the fish diet and their solid excrement are presented in Table 2. N, P, Ca, Mn, Zn and $\mathrm{Cu}$ tended to accumulate in the excrement. The declining tendency of $\mathrm{C}$ may be due to some portions of the $\mathrm{C}$ compounds were converted to fish body and some of them converted to $\mathrm{CO}_{2}$. Concentration of $\mathrm{K}$ in the diet was much lower than that of $\mathrm{Na}$. Ratio of $\mathrm{K} / \mathrm{Na}$ is lower than most plant requirements. Therefore, $\mathrm{K}$ should be supplemented into the system. Seawright et al. (1998) fed Nile tilapia with a commercial diet which higher K than Na. This type of diet is not available in Thailand. The $\mathrm{K}$ and Na concentrations in the excrement were lower than those in the diet because both elements are easily dissolved. The Fe concentration in the excrement was remarkably higher than that in the diet, probably due to contamination of added $\mathrm{Fe}$.

Table 2. Chemical compositions of diet and solid excrement (dry weight basis)

\begin{tabular}{llll}
\hline Elements & Units & Fish diet & Fish excrement \\
\hline $\mathrm{C}$ & $\mathrm{g} / \mathrm{kg}$ & 410.7 & 394.6 \\
$\mathrm{~N}$ & $\mathrm{~g} / \mathrm{kg}$ & 50.9 & 62.4 \\
$\mathrm{P}$ & $\mathrm{g} / \mathrm{kg}$ & 9.2 & 11.4 \\
$\mathrm{~K}$ & $\mathrm{~g} / \mathrm{kg}$ & 8.5 & 2.0 \\
$\mathrm{Na}$ & $\mathrm{g} / \mathrm{kg}$ & 132.6 & 75.7 \\
$\mathrm{Ca}$ & $\mathrm{g} / \mathrm{kg}$ & 16.7 & 21.9 \\
$\mathrm{Mg}$ & $\mathrm{g} / \mathrm{kg}$ & 2.2 & 2.7 \\
$\mathrm{Fe}$ & $\mathrm{mg} / \mathrm{kg}$ & 498 & 2,786 \\
$\mathrm{Mn}$ & $\mathrm{mg} / \mathrm{kg}$ & 52 & 99 \\
$\mathrm{Zn}$ & $\mathrm{mg} / \mathrm{kg}$ & 117 & 863 \\
$\mathrm{Cu}$ & $\mathrm{mg} / \mathrm{kg}$ & 12 & 157 \\
\hline
\end{tabular}

\subsection{Water Quality and Nutrient Dynamics}

The water $\mathrm{pH}$ increased from 6.0 at the beginning of culture and reaching $7.0 \pm 0.1$ at equilibrium from the $4^{\text {th }}$ week of culture until the end of the experiment without adding of acid or alkali (Figure 3). Neutral $\mathrm{pH}$ is the best compromised for all living organisms in aquaponic systems. Acidic $\mathrm{pH}$ retards nitrification and increases $\mathrm{N}_{2} \mathrm{O}$ 
emission, whereas alkali $\mathrm{pH}$ affects the availability of nutrients to the plants. The maximum efficiency of $\mathrm{N}$ use in a media-based aquaponic system is achieved when the $\mathrm{pH}$ is maintained at 6.4 (Zou et al., 2016). Tyson et al. (2008) found that $\mathrm{NH}_{3} / \mathrm{NH}_{4}{ }^{+}$is removed at rates of 19,31 and $80 \mathrm{~g}-\mathrm{N} / \mathrm{m}^{3} /$ day in aquaponic systems operated at $\mathrm{pH}$ 6.0, 7.0 and 8.0, respectively. The dissolution of $\mathrm{CaCO}_{3}$ from the dead corals provided excellent role for $\mathrm{pH}$ control. Lam et al. (2015) was also successful in using corals for maintaining the $\mathrm{pH}$ of an aquaponic system within $\pm 0.2 \mathrm{pH}$ units. However, the equilibrium $\mathrm{pH}$ tended to decrease with decreasing volume ratio of hydroponic trough to rearing tank. Alkalinity of 100 to $150 \mathrm{mg} / \mathrm{L}$ as $\mathrm{CaCO}_{3}$ is generally recommended for $\mathrm{pH}$ buffering in aquaponic systems (Wongkiew et al., 2017).

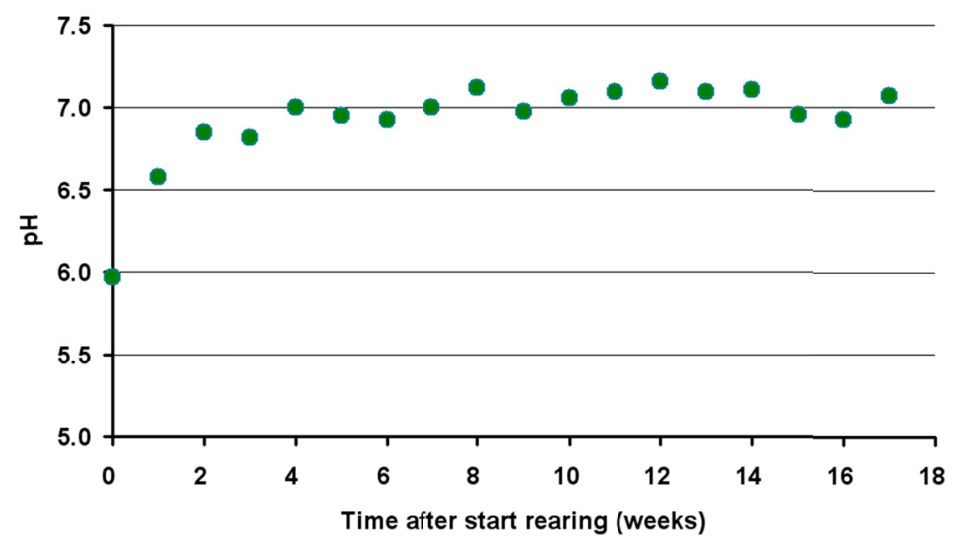

Figure 3. Variation of water $\mathrm{pH}$ in the fish tank over time

The maximum $\mathrm{NH}_{3} / \mathrm{NH}_{4}{ }^{+}$concentration $(10.2 \mathrm{mg}-\mathrm{N} / \mathrm{L})$ was reached by the second week of the experiment and then sharply declined to the range of $0.6 \mathrm{mg}-\mathrm{N} / \mathrm{L}$ to $3.1 \mathrm{mg}-\mathrm{N} / \mathrm{L}$ (Figure 4). Nitrification occurred naturally within two weeks. The $\mathrm{NH}_{3} / \mathrm{NH}_{4}{ }^{+}$concentration should ideally not exceed $1 \mathrm{mg}-\mathrm{N} / \mathrm{L}$ because it affects fish respiration (Connolly \& Trebic, 2010). Increases in $\mathrm{NH}_{3} / \mathrm{NH}_{4}^{+}$to levels above $2 \mathrm{mg}-\mathrm{N} / \mathrm{L}$ occurred because of occasional pipe clogging, which decreased the water flow rate. The feed consumption of fish decreased substantially when $\mathrm{NH}_{3} / \mathrm{NH}_{4}{ }^{+}$concentrations exceeded $2.0 \mathrm{mg}-\mathrm{N} / \mathrm{L}$. The toxicity of $\mathrm{NH}_{3} / \mathrm{NH}_{4}{ }^{+}$depends on the water $\mathrm{pH}$, temperature and aquatic species. At high $\mathrm{pH}$, a higher ratio of total ammonia exists in a more toxic form (unionized form, $\mathrm{NH}_{3}$ ). Warmwater fish are generally more tolerant to $\mathrm{NH}_{3} / \mathrm{NH}_{4}^{+}$than coldwater species, and the former should be considered for aquaponic culture (FAO, 2014; Yildiz et al., 2017). The $\mathrm{NO}_{3}^{-}$ concentration reached a first peak following $\mathrm{NH}_{3} / \mathrm{NH}_{4}^{+}$, because it was transformed from $\mathrm{NH}_{3} / \mathrm{NH}_{4}^{+}$by nitrification. The concentration increased again after $12^{\text {th }}$ week, because vegetable growth was restricted during this period. The $\mathrm{NO}_{3}{ }^{-}$concentration was very low comparison to its toxic level to fish (300 mg-N/L to 400 mg-N/L; Connolly \& Trebic, 2010; Yildiz et al., 2017) and the normal level for hydroponic solution (100 $\mathrm{mg}-\mathrm{N} / \mathrm{L}$ to $200 \mathrm{mg}-\mathrm{N} / \mathrm{L}$; Jones, 1997). The flow rate of water in the system plays a major role in suppressing concentrations of $\mathrm{NH}_{3} / \mathrm{NH}_{4}{ }^{+}$to lower than $1 \mathrm{mg}-\mathrm{N} / \mathrm{L}$. 


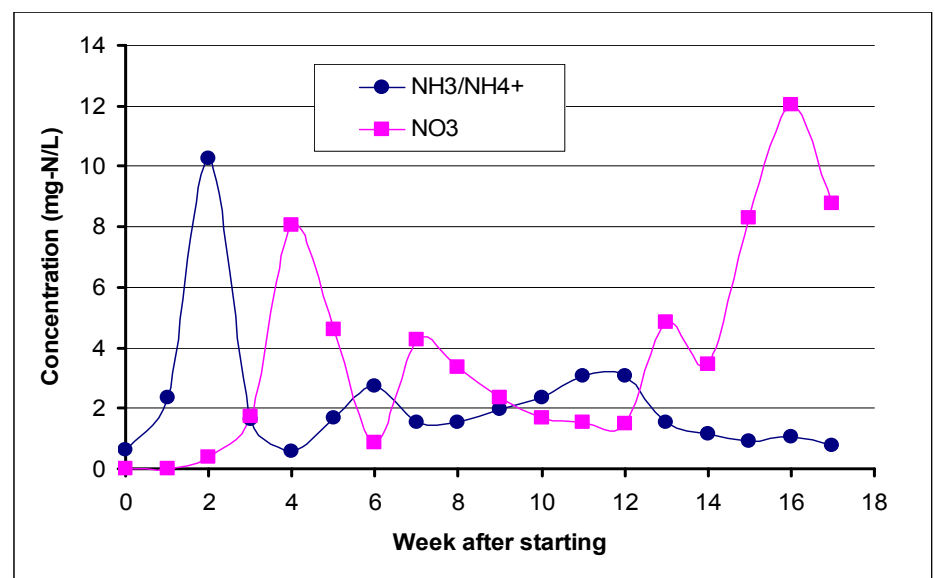

Figure 4. Variation of $\mathrm{NH}_{3} / \mathrm{NH}_{4}{ }^{+}$and $\mathrm{NO}_{3}{ }_{3}$ concentrations in the fish tank over time (input source of the $\mathrm{N}$ came from pellet feed containing $31.8 \%$ protein)

The $\mathrm{K}$ concentration increased from $2.6 \mathrm{mg} / \mathrm{L}$ at the beginning of the experiment to $11.2 \pm 1.8 \mathrm{mg} / \mathrm{L}$, whereas the $\mathrm{Na}$ concentration increased from $3.9 \mathrm{mg} / \mathrm{L}$ to $44.4 \mathrm{mg} / \mathrm{L}$ at the last week of culture (Figure 5). The $\mathrm{K}$ and $\mathrm{Na}$ concentrations showed similar variations and corresponded to the feeding rate (Figure 2). The major source of $\mathrm{K}$ and $\mathrm{Na}$ was the fish diet, which contains a large amount of $\mathrm{Na}$ than $\mathrm{K}$. The ratio of $\mathrm{Na} / \mathrm{K}$ in the diet was 15.6 , but the ratio reduced to $2.6 \pm 0.6(\operatorname{mean} \pm \mathrm{SD})$ in the water. This result indicates that the fish consumed more $\mathrm{Na}$ than $\mathrm{K}$. Vegetable growth at the beginning of culture was better than at later stages, likely due to the lower $\mathrm{Na} / \mathrm{K}$ ratio at the beginning compared with that at later stages of culture. The vegetable showed symptom of K deficiency after $7^{\text {th }}$ week, probably due to the antagonistic effect of $\mathrm{Na}$ on K. Seawright et al. (1998) demonstrated that a large portion of $\mathrm{K}$ is retained by fish; furthermore, fish biomass and $\mathrm{K}$ showed a strong correlation. $\mathrm{K}$ is generally insufficient in aquaponic systems. Thus, $\mathrm{K}$ may be added as $\mathrm{KOH}$ or $\mathrm{K}_{2} \mathrm{CO}_{3}$ to serve both as a nutrient supplement and an acid neutralizing agent (Rakocy et al., 2006; FAO, 2014). Na should be removed, and $\mathrm{K}$ should be supplemented into the system for maintaining a $\mathrm{Na} / \mathrm{K}$ ratio lower than 2 . Partial discharge of the water is an alternative method to prevent $\mathrm{Na}$ accumulation. Jordan et al. (2018) found an accumulation of $\mathrm{Na}$ over $\mathrm{K}$, $\mathrm{Ca}$ and $\mathrm{Mg}$ in their system; subsequently, lettuce growth was not good as grown by a hydroponic method. Rafiee et al. (2018) found that supplementary of hydroponic nutrient solution to electrical conductivity around 0.86 $\mathrm{mS} / \mathrm{cm}$ enhances lettuce yields especially at the beginning of culture. The nutrient concentration al this level did not affect growth of tilapia.

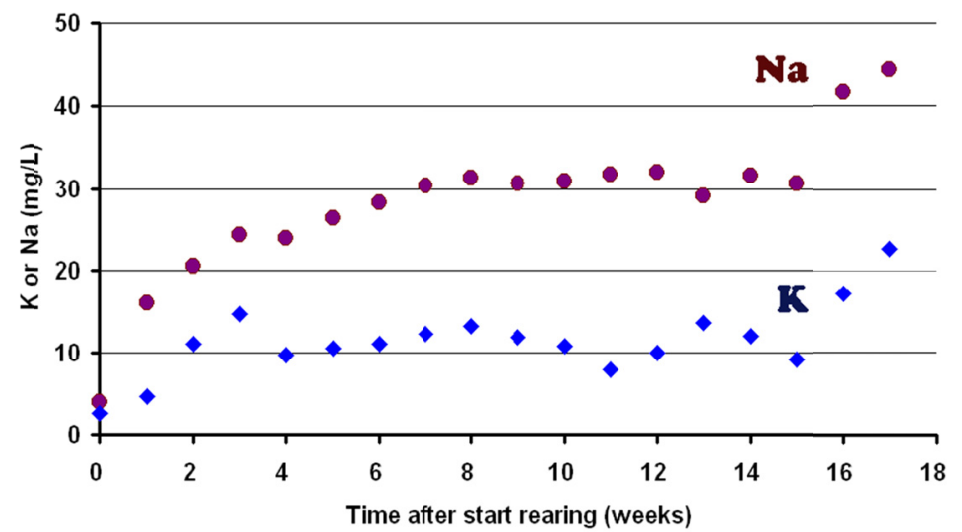

Figure 5. Variation of $\mathrm{K}$ and $\mathrm{Na}$ concentrations in the fish tank over time (input source of the both elements came from pellet feed only)

The Ca concentration increased rapidly at the beginning of culture from $4 \mathrm{mg} / \mathrm{L}$ to $48 \mathrm{mg} / \mathrm{L}$ and then tended to remain constant for the rest of the experiment (Figure 6). Ca release from the dissolution of $\mathrm{CaCO}_{3}$ progresses well under acid condition, but slows down at neutral $\mathrm{pH}$. The dead corals provided both for $\mathrm{pH}$ buffer and $\mathrm{Ca}$ 
source of the system. Ca is one of the common deficiency elements, and it has to be supplemented as $\mathrm{Ca}(\mathrm{OH})_{2}$ or $\mathrm{CaCO}_{3}$ to increase the water hardness to the optimum range of approximately 60 to $140 \mathrm{mg} / \mathrm{L}$ and buffer $\mathrm{pH}$ against acidification from nitrification. Inexpensive sources of $\mathrm{CaCO}_{3}$ such as eggshells, seashells and coarse limestone grit, can be used in the aquaponic systems (FAO, 2014). Seawright et al. (1998) found that Ca concentrations decline rapidly and must be supplemented by $\mathrm{CaCl}_{2} \cdot 6 \mathrm{H}_{2} \mathrm{O}$.

The phosphate, $\mathrm{SO}_{4}{ }^{2-}$ and $\mathrm{Mg}$ concentrations gradually increased in the same trend (Figure 6), thus indicating that assimilation of these nutrients was less extensive than their excretion. Increase rates after $12^{\text {th }}$ week of culture were faster that those in preceding weeks because vegetable growth was highly restricted in later stage. The vegetables growing area should be enlarged to avoid the excessive accumulation of these nutrients. Seawright et al. (1998) found that phosphate concentrations sharply decline because of precipitation of $\mathrm{Ca}_{3}\left(\mathrm{PO}_{4}\right)_{2}$ at heater elements. The water temperature in the present study varied from $23.0{ }^{\circ} \mathrm{C}$ to $33.7{ }^{\circ} \mathrm{C}$; therefore, heating was not required.

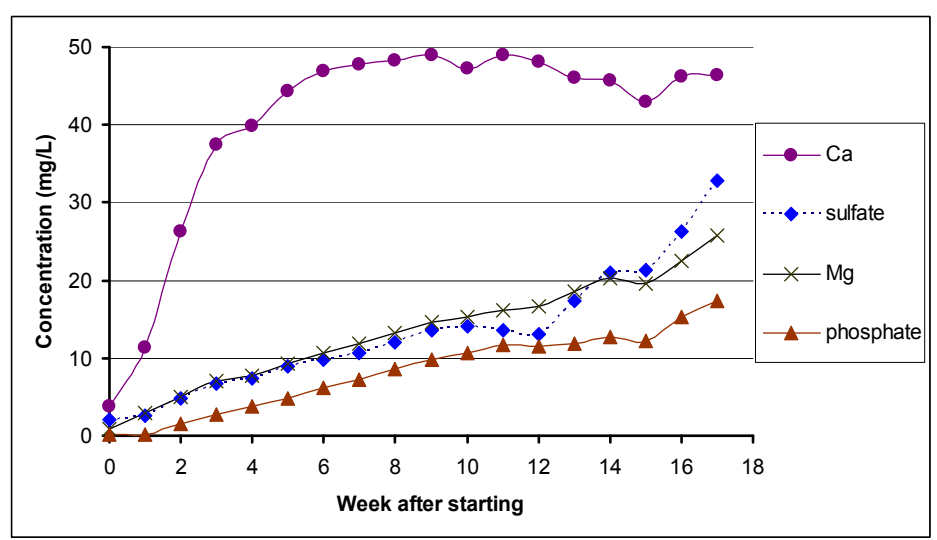

Figure 6. Variation of phosphate, $\mathrm{SO}_{4}{ }^{2-}, \mathrm{Mg}$ and Ca concentrations in the fish tank over time (input source of $\mathrm{Ca}$ came from both pellet feed and dead corals, while the other nutrients came from pellet feed alone)

The Fe concentration sharply increased from $0.2 \mathrm{mg} / \mathrm{L}$ to $1.8 \mathrm{mg} / \mathrm{L}$ in the second week of culture because of addition of Fe-DTPA, and then gradually decreased thereafter (Figure 7). The system required approximately $206 \mathrm{mg}-\mathrm{Fe} / \mathrm{m}^{2}$ per month (equivalent to $1.8 \mathrm{~g} / \mathrm{m}^{2}$ of Fe-DTPA). The pellet feed contained $498 \mathrm{mg} / \mathrm{kg}$ of Fe (Table 2 ), which is insufficient for this system. The low Fe concentration may be a limiting factor resulting in declining vegetable growth after the beginning stage of culture. Fe deficiency is common in aquaponic culture. Therefore, $\mathrm{Fe}$ is regularly added in a form of chelated Fe to a concentration of $2 \mathrm{mg} / \mathrm{L}$ (FAO, 2014) Non-chelated Fe is unstable and precipitates rapidly. Therefore, this form should not be used. Seawright et al. (1998) reported that quantity of Fe consumed by their aquaponic systems exceeded quantity provided by the diet.

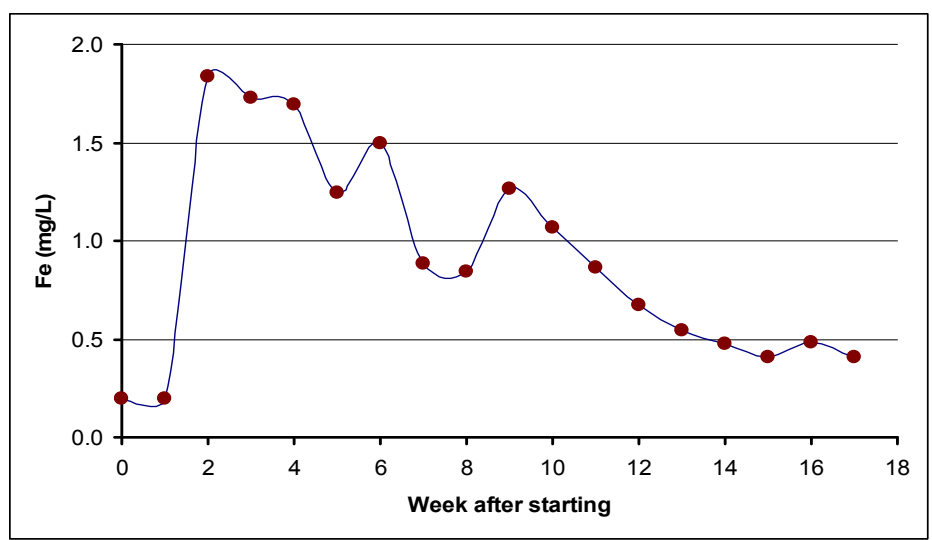

Figure 7. Variation of Fe concentration in the fish tank over time (Fe-DTPA was added to the system during the second week of culture) 


\section{Conclusion}

The aquaponic system achieved well performance for fish production, but it was not successful for vegetable production. Nitrification rapidly occurred and progressed well. $\mathrm{NH}_{3} / \mathrm{NH}_{4}{ }^{+}$accumulated to levels higher than 2 $\mathrm{mg}-\mathrm{N} / \mathrm{L}$ due to clogging in the recirculating pipe. Dissolution of $\mathrm{CaCO}_{3}$ from dead corals sufficiently provided $\mathrm{pH}$ buffer and $\mathrm{Ca}$ source of the system. Phosphate, $\mathrm{SO}_{4}{ }^{2-}, \mathrm{Na}$ and $\mathrm{Mg}$ accumulated in the system, whereas $\mathrm{K}$ and Fe were not sufficient and should be added regularly.

\section{References}

Buurman, P., van Lagen, B., \& Velthorst, E. J. (1996). Manual for Soil and Water Analysis. Leiden, The Netherland: Backhuys Publishers.

Buzby, K. M., Waterland, N. L., Semmens, K. J., \& Lin, L. (2016). Evaluating aquaponic crops in freshwater flow-through fish culture system. Aquaculture, 460, 15-24. https://doi.org/10.1016/j.aquaculture.2016. 03.046

Connolly, K., \& Trebic, T. (2010). Optimization of a backyard aquaponic food production system. Faculty of Agricultural and Environmental Sciences, McGill University.

Edwards, P. (2015). Aquaculture environment interactions: Past, present and likely future trends. Aquaculture, 447, 2-14. https://doi.org/10.1016/j.aquaculture.2015.02.001

Eshchar, M., Lahav, O., Mozes, N., Peduel, A., \& Ron, B. (2006). Intensive fish culture at high ammonia and low pH. Aquaculture, 255, 301-313. https://doi.org/10.1016/j. aquaculture.2005.11.034

FAO. (2014). Small-scale aquaponics food production: Integrated fish and plant farming (FAO Fisheries and Aquaculture Technical Paper No. 589). Rome, Italy: Food and Agriculture Organization of the United Nations.

Hargreaves, J. A., \& Tucker, C. S. (2004). Managing ammonia in fish pond (SRAC Publication No. 4603). Southern Regional Aquaculture Center, United States Department of Agriculture.

Jones, J. B. (1997). Hydroponics : A Practical Guide for the Soilless Grower. Boca Raton, Florida: CRC Press.

Jones, J. B. (2001). Laboratory Guide for Conducting Soil Tests and Plant Analysis. New York, NY: CRC Press. https://doi.org/10.1201/9781420025293

Jordan, R. A., Geisenhoff, L. O., de Oliveira, F. C., Santos, R. C., \& Martins, E. A. S. (2018). Yield of lettuce growth in aquaponics system using different substrates. Revista Brasileira de Engenharia Agricola e Ambiental, 22, 27-31. https://doi.org/10.1590/1807-1929/agriambi.v22n1p27-31

Kamal, S. M. (2006). Aquaponic production of Nile tilapia (Oreochromis niloticus) and bell pepper (Capsicum annuum) in recirculating water system. Egypt J. Aquat. Biol. \& Fish, 10, 85-97. https://doi.org/10.21608/ ejabf.2006.1864

Lam, S. S., Ma, N. L., Jusoh, A., \& Ambak, M. A. (2015). Biological nutrient removal by recirculating aquaponic system: Optimization of the dimension ratio between the hydroponic \& rearing tank components. International Biodeterioration \& Biodegradation, 102, 107-115. https://doi.org/10.1016/j.ibiod.2015.03.012

Lekang, O.-I. (2013). Aquaculture Engineering (2nd ed.). Oxford, UK: Wiley-Blackwell. https://doi.org/10.1002/ 9781118496077

Lennard, W. A., \& Leonard, B. V. (2004). A comparison of reciprocating flow versus constant flow in an integrated, gravel bed, aquaponics test system. Aquaculture International, 12, 539-553. https://doi.org/ 10.1007/s10499-004-8528-2

Perez-Urrestarazu, L., Lobillo-Eguibar, J., \& Fernandez-Canero, R. (2019). Suitability and optimization of FAO's small-scall aquaponics systems for joint production of lettuce (Lactuca sativa) and fish (Carassius auratus). Aquacultural Engineering, 85, 129-137. https://doi.org/10.1016/j.aquaeng.2019.04.001

Rafiee, Gh. R., Ros Saad, Ch., Kamarudin, M. S., Ismail, M. R. \& Sijam, K. (2018). Effects of supplementary nutrient in an aquaponic system for production of ornamental red tilapia (Oreochromis Sp.) and lettuce (Lactuca sativa var Longifolia). International Journal of Ornamental Aquatics Research, 1, 41-51.

Rakocy, J. E. (2012). Aquaponics - Integrating fish and plant culture. In J. H. Tidwell (Ed.), Aquaculture Production Systems. Oxford, UK: John Wiley \& Sons. https://doi.org/10.1002/9781118250105.ch14 
Rakocy, J. E., Masser, M. P., \& Losordo, T. M. (2006). Recirculating aquaculture tank production systems: Aquaponic-integrating fish and plant culture (SRAC Publication No. 454). Southern Regional Aquaculture Center, United States Department of Agriculture.

Rayment, G. E., \& Higginson, V. (1992). Australian Laboratory Handbook of Soil and Water Chemical Methods. Melbourne, Australia: Inkata Press.

Seawright, D. E., Stickney, R. R., \& Walker, R. B. (1998). Nutrient dynamic in integrated aquaculture-hydroponics systems. Aquaculture, 160, 215-237. https://doi.org/10.1016/S0044-8486(97) 00168-3

Tyson, R. V., Simonne, E. H., \& Treadwell, D. D. (2008). Reconciling pH for ammonia biofiltration and cucumber yield in a recirculating aquaponics system with perlite biofilters. HortScience, 43, 719-724. https://doi.org/10.21273/HORTSCI.43.3.719

Wongkiew, S., Hu, Z., Chandran, K., Lee, J. W., \& Khanal, S. K. (2017). Nitrogen transformation in aquaponic systems: A review. Aquaculture Engineering, 76, 9-19. https://doi.org/10.1016/j.aquaeng.2017.01.004

Yildiz, H. Y., Robaina, L., Pirhonen, J., Mente, E., Dominguez, D., \& Parisi, G. (2017). Fish welfare in aquaponic systems: Its relation to water quality with an emphasis on feed and faeces-A Review. Water, 9, 1-17. https://doi.org/10.3390/w9010013

Zou, Y., Hu, Z., Zhang, J., Xie, H., Guimbaud, C., \& Fang, Y. (2016). Effects of pH on nitrogen transformation in media-based aquaponics. Bioresources Technology, 210, 81-87. https://doi.org/10.1016/j.biortech.2015. 12.079

\section{Copyrights}

Copyright for this article is retained by the author(s), with first publication rights granted to the journal.

This is an open-access article distributed under the terms and conditions of the Creative Commons Attribution license (http://creativecommons.org/licenses/by/4.0/). 